\title{
Antifungal and Antibiofilm Activities of Selective Serotonin Reuptake Inhibitors Alone and in Combination with Fluconazole
}

\section{Selektif Serotonin Geri Alım İnhibitörlerinin Tek Başına ve Flukonazol ile Kombinasyonlarının Antifungal ve Antibiyofilm Aktiviteleri}

\author{
(D) Mine HOŞGÖR LIMONCU2* \\ 1'zmir Katip Çelebi University Faculty of Pharmacy, Department of Pharmaceutical Microbiology, İzmir, Turkey \\ 2Ege University Faculty of Pharmacy, Department of Pharmaceutical Microbiology, İzmir, Turkey \\ ${ }^{3}$ Ege University Faculty of Medicine, Department of Medical Microbiology, İmir, Turkey
}

(D) Yamaç TEKINTAȘ1, (D) Aybala TEMEL1', (D) Ayșegül ATEŞ22, (D) Bayrı ERAÇ22, (D) Dilek Yeșim METIN³, (D) Süleyha HILMIOĞLU POLAT33,

\begin{abstract}
Objectives: Candida spp. are clinically important pathogens that cause difficulties for treatment by biofilm formation. Considering antifungal resistance rates and the limitations in the discovery of new antifungals, the antifungal and antibiofilm effects of various drugs used for different therapeutic purposes are becoming more important. The goal of our study was to determine the antifungal and antibiofilm effects of the selective serotonin reuptake inhibitors (SSRIs), namely sertraline (SRT), paroxetine (PRX), and fluoxetine (FLX) alone and in combination with fluconazole (FLC) against Candida spp.

Materials and Methods: Twenty Candida spp. strains isolated from clinical samples from Ege University Hospital were identified by the Dalmau method and matrix-assisted laser desorption ionization time of flight mass spectrometry. The minimum inhibitory concentrations (MICs) of the SSRIs and FLC were detected by broth microdilution method. Synergistic interactions between the SSRIs and FLC were investigated by checkerboard assay. The antibiofilm effects of the SSRIs were determined by spectrophotometric microplate method.

Results: Among the isolates, five different Candida spp. (C. albicans, C. glabrata, C. krusei, C. tropicalis, and C.parapsilosis) were identified. The MICs of the SSRIs ranged between $16-512 \mu \mathrm{g} / \mathrm{mL}$. While SRT showed the highest antifungal effect, the antibiofilm efficacy of FLX was higher than that of the other agents. Moreover, FLX and PRX showed a synergistic effect with FLC in 13 and 19 isolates, respectively. Four isolates were strong biofilm producers while nine isolates were moderate biofilm producers. C. parapsilosis strains showed higher biofilm production than the other species. At MIC/2 concentration, FLX and SRT alone inhibited mature biofilms in six and five isolates, respectively, while PRX caused increases biofilm formation in seven isolates.

Conclusion: This study revealed that MIC/2 concentrations of SSRIs could have antifungal and antibiofilm effects. SRT and FLX alone or in combination with antifungals may possibly have therapeutic potential for combating fungal infections.
\end{abstract}

Key words: Candida spp., fluconazole, EUCAST, synergistic effect, antibiofilm

Öz

Amaç: Klinik açıdan önemli fungal patojenlerden olan Candida türleri, biyofilm üretme kapasiteleriyle tedavide zorluklara yol açmaktadır. Antifungal direnç oranları ve yeni antifungallerin keşfinin sınırlıı̆ı göz önüne alındığında, farklı terapötik amaç için kullanılan çeşitli ilaç moleküllerinin antifungal ve antibiyofilm etkileri daha fazla önem kazanmaktadır. Çalıșmamızın amacı, selektif serotonin geri alım inhibitörleri (SSRI) olan sertralin (SRT), paroksetin (PRX), fluoksetinin (FLX), tek başına ve flukonazol (FLC) ile kombine halde Candida türlerine karşı antifungal ve antibiyofilm etkilerinin belirlenmesidir.

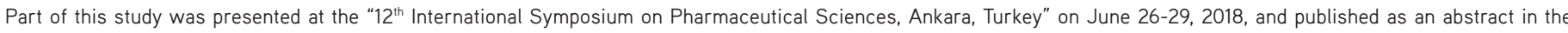
abstract book p 138 .

*Correspondence: E-mail: minehosgorlimoncu@yahoo.com.tr, Phone: +90 2323113983 ORCID-ID: orcid.org/0000-0002-4892-8639

Received: 27.09.2019, Accepted: 14.11.2019

OTurk J Pharm Sci, Published by Galenos Publishing House. 
Gereç ve Yöntemler: Ege Üniversitesi Hastanesi'nde klinik örneklerden izole edilen 20 Candida spp. kökeni Dalmau metodu ve Matriks aracılı lazer dezorpsiyon/iyonizasyon uçuş zamanı kütle spektrometresi kullanılarak tanımlanmıștır. SSRI moleküllerin ve FLC'nin minimum inhibitör konsantrasyon (MIC) değerleri sıvı mikrodilüsyon yöntemiyle belirlenmiştir. FLC ve SSRI moleküllerin sinerjistik etkileşimleri dama tahtası metoduyla araştırılmıştır. SSRI'ların antibiyofilm etkinlikleri spektrofotometrik mikroplaka yöntemiyle değerlendirilmiştir.

Bulgular: Yirmi izolat arasında beş farklı Candida türü (C. albicans, C. glabrata, C. krusei, C. tropicalis ve C. parapsilosis) belirlenmiştir. SSRI'ların MIC değerlerinin 16-512 $\mathrm{gg} / \mathrm{mL}$ aralığında değiştiği saptanmıştır. SRT'nin yüksek antifungal etkisi gözlenirken, FLX'in antibiyofilm etkinliğinin diğer ajanlardan daha yüksek olduğu belirlenmiştir. Ayrıca, FLX ve PRX'in FLC ile kombinasyonlarında sırasıyla on üç ve on izolat üzerinde sinerjistik etkisi görülmüștür. Dört izolatın güçlü, dokuz izolatın ise orta düzey biyofilm üreticisi olduğu saptanmıștır. C. parapsilosis sușlarının biyofilm üretim kapasitelerinin diğer türlerden daha yüksek olduğu gözlenmiştir. MIC/2 konsantrasyonda, tek başlarına FLX ve SRT sırasıyla altı ve beş izolatta olgun biyofilm üzerinde inhibe edici etki gösterirken, PRX'in yedi izolatın biyofilm oluşumunda artışa yol açtığı saptanmıştır.

Sonuç: Bu çalıșma, SSRI'ların MIC/2 konsantrasyonlarda antifungal ve antibiyofilm etkinliklerinin olabileceğini göstermiştir. SRT ve FLX'in tek başına veya antifungal ajanlarla kombine kullanımının fungal enfeksiyonlarla mücadelede terapötik potansiyeli olabilir.

Anahtar kelimeler: Candida spp., flukonazol, EUCAST, sinerjistik etki, antibiyofilm

\section{INTRODUCTION}

Fungal infections have received attention due to their higher prevalence and mortality rates in recent years.' Among the clinically important yeasts, Candida spp. are some of the most common opportunistic pathogens. Although species of this genus may live as members of the microbiota in healthy individuals, they may cause life-threatening infections in hospitalized and immunosuppressed patients. ${ }^{2,3}$ One of the major reasons causing the increase in Candida infections is thought to be the greater use of medical devices such as catheters, cardiac pacemakers, or artificial hearts, which have suitable surfaces for biofilm formation. ${ }^{4} \mathrm{~A}$ biofilm is a group of microbial cells embedded in extracellular polymeric substances, and recent studies have shown that these sessile cells in biofilms are much more resistant to both antimicrobials and host defense mechanisms compared to planktonic cells due to reduced penetration. ${ }^{5}$

The increased resistance rates to antifungals, the high biofilm production capacities, and the fact that certain Candida species are inherently resistant to some antifungals suggest that new antifungal molecules are needed for therapy. Because of the eukaryotic cell structures of fungal pathogens, antifungals should have selective mechanisms that target specific structures in microorganisms different from human cells. This situation makes it difficult to develop new antifungal agents. Consequently, it is becoming more and more beneficial to investigate the antifungal and antibiofilm activities of various molecules used for diverse therapeutic purposes.

Selective serotonin reuptake inhibitors (SSRIs) are used as antidepressants and as the first-line therapy for premenstrual syndrome. The antifungal activities of these agents were first discovered when three patients with chronic vulvovaginal candidiasis treated with sertraline (SRT) for premenstrual syndrome presented no symptoms of candidiasis during the treatment course. ${ }^{6}$ Based on this knowledge, different studies have shown that these agents may have antifungal effects on yeast species. The main goal of the present study was to determine the antimicrobial activity and antibiofilm effects of SSRIs alone and in combination with fluconazole (FLC) against clinical Candida spp. isolates.

\section{MATERIALS AND METHODS}

\section{Fungal isolates and identification}

Twenty Candida spp. isolated from patients samples at Ege University Hospital, Mycology Laboratory of Medical Microbiology Department and Candida parapsilosis ATCC 22019 strain were examined. The yeast species were identified by the Dalmau method and matrix-assisted laser desorption ionization time of flight mass spectrometry (MALDI TOF-MS).

\section{Agent solutions}

FLC (Sigma, USA), fluoxetine (FLX) (Abdi Ibrahim, Turkey), paroxetine (PRX) (ARIS, Turkey), and SRT (Sanovel, Turkey) were provided in powder form. The agents were dissolved with using sterile water and dimethyl sulfoxide to a final concentration of $4096 \mu \mathrm{g} / \mathrm{mL}$. The stock solutions were stored at $-80^{\circ} \mathrm{C}$ until use.

Determination of minimum inhibitory concentrations (MICs)

MICs of the SSRIs and FLC were determined by broth microdilution method according to European Committee for Antimicrobial Susceptibility Testing (EUCAST) criteria. ${ }^{7}$ Firstly, an appropriate volume of RPMI-1640 (Sigma, USA) supplemented with $2 \%$ glucose (Sigma, USA) was buffered with $0.165 \mathrm{M}$ MOPS (Sigma, USA) at pH 7.0. Then the medium was added to 96-well U-bottom microplates. The agent solutions were added to the first well of the microplates and serially diluted. Fungal inoculums $\left(1 \times 10^{6}\right.$ cells) were added to the wells and the microplates were incubated at $37^{\circ} \mathrm{C}$ for $24 \mathrm{~h}$. After incubation, the absorbance values were measured at 570 $\mathrm{nm}$ by spectrophotometric microplate reader (Varioskan Flash, Thermo Scientific, USA). The drug concentration that led to an approximately $50 \%$ reduction in growth relative to the drug-free well was accepted as the MIC. All experiments were performed in triplicate. The statistical analyses were performed using GraphPad Prism 5.03 (t-test).

\section{Checkerboard assays}

Interaction types between the SSRI agents and FLC were determined using the checkerboard method in 96-well plates. The types of interaction between the SSRI agents and FLC were evaluated based on the fractional inhibitory index (FIX) and the fractional inhibitory concentration (FIC) values for each combination. The following formulae were used to calculate the 
FIC index:

FIC of drug A: (MIC of drug A in combination) / (MIC of drug A alone)

FIC index (FIX): (FIC of drug A) + (FIC of drug B)

Synergistic, indifferent, and antagonist interactions were defined by FIX values of $\langle 0.5,0.5$ to 4 , and $\rangle 4$, respectively. ${ }^{8}$

\section{Biofilm formation and quantification}

Biofilm formation was also quantified by a modification of the crystal violet (CV) staining assay. ${ }^{9}$ Briefly, $100 \mu \mathrm{L}$ of standardized Candida spp. cell suspensions prepared in tryptic soy broth (TSB) medium (Oxoid, UK) ( $1 \times 10^{6}$ cells) were transferred into wells of sterile, flat-bottomed, polystyrene 96 -well microplates. The microplates were incubated at $37^{\circ} \mathrm{C}$ for $24 \mathrm{~h}$ for biofilm production. Following incubation, the cell suspensions were aspirated and the wells were washed three times with sterile phosphate buffered saline (PBS) (Oxoid, UK) $200 \mu \mathrm{L}$ per well in order to remove nonadherent cells. After each washing step, the microplates were air dried to remove the PBS. Afterwards, the remaining attached microorganisms were fixed with $200 \mu \mathrm{L}$ of methanol for $15 \mathrm{~min}$. The contents of the wells were poured off, the methanol was discarded, and the wells were air-dried. Then $200 \mu \mathrm{L}$ of $0.02 \%$ CV solution was added to the wells for $20 \mathrm{~min}$ at room temperature. After $20 \mathrm{~min}$, the CV solution was removed by washing with $\mathrm{PBS}$ and the microplates were dried. Each well was destained with $200 \mu \mathrm{L}$ of $95 \%$ ethanol for 15 min. Biofilm formation was quantified by measuring the optical density (OD) at $570 \mathrm{~nm}$ using a microplate reader (Varioskan Flash, Thermo Scientific, USA). OD values of wells without inoculum were used as negative controls. Enterococcus faecalis ATCC 29212 was used as a positive control strain. The cutoff OD (ODc) was defined as three standard deviations above the mean $\mathrm{OD}$ of the negative controls. The biofilm production capacities of the isolates were evaluated as shown in Table 1. All tests were carried out in triplicate. The statistical analyses were performed using GraphPad Prism 5.03 (t-test).

\section{Antibiofilm effects of SSR/s}

The antibiofilm effects of the SSRI agents at sub-MICs (MIC/2, $\mathrm{MIC} / 4$ ) were investigated by CV staining assay. Biofilm formation was performed by adding standardized cell suspensions to the wells of the microplates and incubating them for $24 \mathrm{~h}$ at $37^{\circ} \mathrm{C}$ as described above. After biofilm formation, the medium in the wells was aspirated, and nonadherent cells were removed by thoroughly washing all wells three times with sterile PBS. The SSRI agent solutions at sub-MICs (MIC/2 and $\mathrm{MIC} / 4$ ) were prepared in TSB and added to the wells that contained preformed biofilm. After these agents were added to the wells, the microplates were incubated for a further $24 \mathrm{~h}$ at $37^{\circ} \mathrm{C}$. Then

Table 1. Categorizations of biofilm production capacities

\begin{tabular}{ll}
$O D \leq O D c$ & No biofilm production \\
\hline$O D c<O D \leq(2 \times O D c)$ & Weak biofilm producer \\
\hline$(2 \times O D c)<O D \leq(4 \times O D c)$ & Moderate biofilm producer \\
\hline$(4 \times O D c)<O D$ & Strong biofilm producer \\
\hline
\end{tabular}

$\mathrm{OD}$ : Optical density of the isolate, ODc: The mean OD of negative controls the CV staining assay was performed. The antibiofilm effects of the agents were evaluated by measuring the OD of the wells at $570 \mathrm{~nm}$ using a microplate reader.

\section{Statistical analysis}

All tests were carried out in triplicate. The ODc was defined as three standard deviations above the mean OD of the negative controls. The statistical analyses were performed using GraphPad Prism 5.03 (t-test) and p<0.05 was considered statistically significant.

\section{RESULTS}

\section{Fungal isolates and identification}

The 20 clinical fungal isolates identified comprised six C. albicans, four C. tropicalis, four C. krusei, three C. parapsilosis, and three $C$. glabrata according to the Dalmau method and MALDITOF-MS.

\section{Minimum inhibitory concentrations of fluconazole and SSR/s}

Two isolates were resistant to FLC in addition to the inherently resistant $C$. krusei isolates. The MICs of SRT ranged from $16 \mu \mathrm{g} /$ $\mathrm{mL}$ to $128 \mu \mathrm{g} / \mathrm{mL}$ by the broth microdilution method, while the MICs of PRX and FLX ranged from $64 \mu \mathrm{g} / \mathrm{mL}$ to $512 \mu \mathrm{g} / \mathrm{mL}$. The MICs of all agents are shown in Table 2.

\begin{tabular}{|c|c|c|c|c|}
\hline Isolate & $\begin{array}{l}\text { FLC } \\
(\mu \mathrm{g} / \mathrm{mL})\end{array}$ & $\begin{array}{l}\text { SRT } \\
(\mu \mathrm{g} / \mathrm{mL})\end{array}$ & $\begin{array}{l}\text { PRX } \\
(\mu \mathrm{g} / \mathrm{mL})\end{array}$ & $\begin{array}{l}\text { FLU } \\
(\mu \mathrm{g} / \mathrm{mL})\end{array}$ \\
\hline Candida glabrata & 16 & 128 & 256 & 512 \\
\hline Candida glabrata & 16 & 128 & 256 & 512 \\
\hline Candida glabrata & 16 & 128 & 256 & 512 \\
\hline Candida albicans & 0.25 & 128 & 256 & 512 \\
\hline Candida albicans & 0.25 & 128 & 256 & 512 \\
\hline Candida albicans & 0.25 & 128 & 256 & 256 \\
\hline Candida albicans & 2 & 64 & 256 & 256 \\
\hline Candida albicans & 1 & 64 & 256 & 256 \\
\hline Candida albicans & 8 & 64 & 256 & 256 \\
\hline Candida tropicalis & 1 & 32 & 128 & 128 \\
\hline Candida tropicalis & 0.5 & 32 & 128 & 128 \\
\hline Candida tropicalis & 4 & 32 & 128 & 256 \\
\hline Candida tropicalis & 0.5 & 32 & 128 & 128 \\
\hline Candida krusei* & - & 64 & 64 & 128 \\
\hline Candida krusei* & - & 32 & 64 & 128 \\
\hline Candida krusei* & - & 32 & 64 & 64 \\
\hline Candida krusei* & - & 16 & 128 & 128 \\
\hline Candida parapsilosis & 16 & 64 & 256 & 256 \\
\hline Candida parapsilosis & 1 & 32 & 512 & 512 \\
\hline Candida parapsilosis & 1 & 32 & 256 & 512 \\
\hline $\begin{array}{l}\text { Candida parapsilosis ATCC } \\
22019\end{array}$ & 2 & 128 & 256 & 512 \\
\hline
\end{tabular}

*Intrinsically resistant to fluconazole, SSRIs: Selective serotonin reuptake inhibitors, SRT: Sertraline, PRX: Paroxetine, FLU: Fluoxetine, FLC: Fluconazole 


\section{Checkerboard assay}

The interactions between the SSRI agents and FLC were examined by checkerboard assay. No antagonism was found between the agents tested. FLX showed a synergistic effect in the large number of isolates when it was compared to the other SSRIs. It was also determined that FLX is the only agent showing a synergistic interaction with FLC against five different Candida species. According to the checkerboard assay, SRT, FLX, and PRX were synergistic in six, thirteen, and ten isolates, respectively. The interaction types of the SSRI agents are shown in Table 3.

\section{Biofilm formation and quantification}

The biofilm quantification assays revealed that seven of the isolates have weak biofilm production capacity, nine isolates show moderate biofilm production, and four isolates have strong biofilm production capacity. The biofilm production capacities and the number of isolates are shown in Table 4.

\section{Antibiofilm effects of SSRIs}

In the presence of MIC/2 of FLX, biofilm formation decreased in six isolates, while it increased in two isolates. PRX and SRT, at $\mathrm{MIC} / 2$, inhibited biofilm in three and five isolates, respectively. The effects of sub-MIC of the SSRIs on mature biofilm formation in moderate and strong biofilm producer isolates are shown in Table 5.

\begin{tabular}{|c|c|c|c|}
\hline \multirow[b]{2}{*}{ Candida spp. } & \multicolumn{3}{|c|}{ Biofilm production capacity } \\
\hline & Weak & Moderate & Strong \\
\hline Candida albicans $(n=6)$ & 3 & 3 & - \\
\hline Candida parapsilosis $(\mathrm{n}=3)$ & - & - & 3 \\
\hline Candida krusei $(\mathrm{n}=4)$ & 2 & 2 & - \\
\hline Candida tropicalis $(n=4)$ & 1 & 2 & 1 \\
\hline Candida glabrata $(\mathrm{n}=3)$ & 1 & 2 & - \\
\hline
\end{tabular}

Table 5. The effects of SSRIs on mature biofilm formation of the isolates

\begin{tabular}{lllllll}
\hline $\begin{array}{l}\text { Number of isolates } \\
\begin{array}{l}\text { offects } \\
\text { biofilm }\end{array}\end{array}$ & $\begin{array}{l}\text { FLX } \\
(\mathrm{MIC} / 2)\end{array}$ & $\begin{array}{l}\text { FLX } \\
(\mathrm{MIC} / 4)\end{array}$ & $\begin{array}{l}\mathrm{PRX} \\
(\mathrm{MIC} / 2)\end{array}$ & $\begin{array}{l}\mathrm{PRX} \\
(\mathrm{MIC} / 4)\end{array}$ & $\begin{array}{l}\mathrm{SRT} \\
(\mathrm{MIC} / 2)\end{array}$ & $\begin{array}{l}\mathrm{SRT} \\
(\mathrm{MIC} / 4)\end{array}$ \\
\hline Decrease & 6 & 4 & 3 & - & 5 & 3 \\
\hline Increase & 2 & 4 & 7 & 7 & 3 & 3 \\
\hline No effect & 5 & 5 & 3 & 6 & 5 & 7 \\
\hline
\end{tabular}

SSRIs: Selective serotonin reuptake inhibitors, FLX: Fluoxetine, PRX: Paroxetine, SRT: Sertraline, MIC: Minimum inhibitory concentration

Table 3. Interaction types between SSRIs and fluconazole (FIX values)

\begin{tabular}{|c|c|c|c|c|c|c|}
\hline & $\mathrm{FLC}+\mathrm{FL}$ & & $\mathrm{FLC}+\mathrm{SR}$ & & $\mathrm{FLC}+\mathrm{PF}$ & \\
\hline Isolate & FIX & Profile & FIX & Profile & FIX & Profile \\
\hline Candida glabrata & 0.5078 & I & 0.5156 & $\mathrm{I}$ & 0.2656 & $\mathrm{~s}$ \\
\hline Candida glabrata & 0.375 & $\mathrm{~s}$ & 0.5156 & 1 & 0.2656 & $\mathrm{~s}$ \\
\hline Candida glabrata & 0.5 & $\mathrm{~s}$ & 0.5156 & 1 & 0.2656 & $\mathrm{~s}$ \\
\hline Candida albicans & 0.375 & S & 0.625 & 1 & 0.75 & 1 \\
\hline Candida albicans & 0.5 & S & 1.0313 & I & 0.75 & I \\
\hline Candida albicans & 0.5 & $\mathrm{~s}$ & 1.25 & 1 & 0.75 & 1 \\
\hline Candida albicans & 0.2813 & S & 0.3125 & S & 0.1563 & $S$ \\
\hline Candida albicans & 0.1406 & S & 1.5 & 1 & 0.75 & 1 \\
\hline Candida albicans & 1.0625 & 1 & 1 & I & 1 & 1 \\
\hline Candida tropicalis & 0.5 & $\mathrm{~s}$ & 1.5 & 1 & 0.75 & $\mathrm{I}$ \\
\hline Candida tropicalis & 1.0625 & 1 & 2 & I & 1.5 & I \\
\hline Candida tropicalis & 0.2656 & S & 0.375 & $\mathrm{~s}$ & 0.5 & $\mathrm{~s}$ \\
\hline Candida tropicalis & 1.0625 & 1 & 2 & 1 & 1 & 1 \\
\hline Candida krusei* & 0.625 & I & 0.25 & $\mathrm{~s}$ & 0.5 & $\mathrm{~s}$ \\
\hline Candida krusei* & 0.5 & $\mathrm{~s}$ & 0.5 & $\mathrm{~s}$ & 0.375 & $\mathrm{~s}$ \\
\hline Candida krusei* & 0.5 & S & 0.5 & $S$ & 0.375 & $\mathrm{~S}$ \\
\hline Candida krusei* & 0.2813 & $\mathrm{~s}$ & 0.75 & I & 0.25 & $\mathrm{~s}$ \\
\hline Candida parapsilosis & 0.3125 & $\mathrm{~s}$ & 0.25 & $\mathrm{~s}$ & 0.2813 & $\mathrm{~S}$ \\
\hline Candida parapsilosis & 1.0078 & I & 1.125 & I & 1.0078 & I \\
\hline Candida parapsilosis & 1.0156 & 1 & 1.25 & 1 & 1.0156 & I \\
\hline Candida parapsilosis ATCC 22019 & 0.5 & $\mathrm{~s}$ & 0.2656 & $\mathrm{~s}$ & 0.625 & I \\
\hline
\end{tabular}

*Intrinsically resistant to fluconazole, SSRIs: Selective serotonin reuptake inhibitors, FLC: Fluconazole, FLX: Fluoxetine, PRX: Paroxetine, SRT: Sertraline, FIX: Fractional inhibitory index, S: Synergistic, I: Indifferent 


\section{DISCUSSION}

The significant increase in fungal infections over the past decade has increased the need for new antifungal agents and reliable and reproducible susceptibility testing methods. ${ }^{10}$ There are two reference in vitro antifungal susceptibility testing methods for Candida spp. These reference methods have been developed by two scientific organizations, namely the Clinical and Laboratory Standards Institute and the EUCAST. Despite the differences such as in terms of media, plate types, and measurement methods between these methods, it was determined in several studies that these two methods give results consistent with each other. ${ }^{10}$ Although the EUCAST method requires more material and equipment, it has the significant advantage of producing results after a 24-h incubation. Moreover, the measurement of absorbance by the automated device in the EUCAST method, instead of visual inspection, will be the major factor that reduces the error rate. Considering these reasons, we first investigated the in vitro activity of SSRIs and FLC by broth microdilution method according to EUCAST. The agent concentration that led to approximately $50 \%$ inhibition of growth relative to the controls, which was determined spectrophotometrically, was accepted as the MIC value (Table 2).

SRT was the prominent molecule with a lower MIC range (16-128 $\mathrm{mg} / \mathrm{mL}$ ) compared to FLX and PRX. According to the literature, SRT is generally more effective than the others, which is consistent with our study. In a study conducted on Candida spp., it was determined that SRT has antifungal effects on Candida species and it was also reported that SRT inhibits Candida virulence factors. ${ }^{6}$ The inhibitory effects of SRT on different yeasts species, such as Cryptococcus isolates, are also shown by research.11

There are studies showing that FLX had antibiofilm activity at previously reported MIC values and even at sub-MIC values in the literature. ${ }^{12}$ Oliveira et al..$^{12}$ reported that FLX was able to reduce biofilm metabolism at high concentrations by $96 \%$ (C. krusei) and biofilm biomass by $82 \%$ (C. glabrata), when compared to the control. They also detected that SRT achieved a reduction of $88 \%$ in biofilm biomass (C. glabrata) and $90 \%$ in biofilm metabolism (C. parapsilosis) under similar conditions. According to our results, FLX, at sub-MIC concentrations, showed an antibiofilm effect in six isolates, while SRT showed an antibiofilm effect in five isolates. It was also interesting that FLX's MIC ranges were lower on C. krusei isolates compared to other Candida species.

Unlike SRT and FLX, the number of studies about the antifungal effects of PRX is very limited in the literature. However, the results of a study conducted by Costa Silva et al..$^{13}$ and our data showed that PRX has antifungal activity at high concentrations. In parallel to this finding, the MICs of PRX were higher than those of FLX and PRX in our study. Considering our results on the antibiofilm effects of PRX, it was noteworthy that PRX, at $\mathrm{MIC} / 2$ levels, caused an increase in biofilm formation of seven isolates.

Even though it is not fully understood how SSRI agents provide their antifungal activities, the point of interest is that their antifungal activity is independent of the species and resistance properties of the Candida isolates. In a study investigating this situation, it was reported that the lethal effect of the agents is related to the induction of apoptosis due to damage to the plasma and mitochondrial membranes. It is thought that this condition may be related to genetic variation rather than factors such as species and resistance patterns. ${ }^{13}$ Although antifungal activities of SSRIs have been shown in many studies in the literature, it is necessary to know more about the pharmacokinetics of these molecules, which are usually taken orally in clinical practice. The optimum concentrations that will be reached for these agents in several infection sites should be investigated in new studies. Considering the plasma drug concentration of SSRIs, it appears that the doses required for Candida inhibition are above the commonly used doses of these drugs. ${ }^{14,15}$ On the other hand, it should be kept in mind that the commonly used dosage regimens and pharmacokinetic data of these drugs are regulated for oral therapeutic use. Undoubtedly, more research is needed to evaluate using different forms such as topical formulations of SSRIs as an antimicrobial agent.

A correlation between biofilm formation and antimicrobial resistance profiles was already shown in different studies and so the antibiofilm activities of drug molecules that have various known therapeutic effects are also gaining importance.16,17 Therefore, we also analyzed the antibiofilm effects of SSRI molecules against mature biofilm of Candida isolates. Several different methods and devices could be used for the detection of biofilm formation such as the CV staining assay, light and fluorescence microscopy, bioluminescence, Congo red agar, and Christensen methods. The CV staining assay was used in our study, especially because more sensitive, specific, and quantitative results can be obtained by this method. ${ }^{18,19}$ It has been demonstrated with the results of many studies that all Candida species could have biofilm forming ability. ${ }^{20}$ In parallel with these data, the isolates in the present study identified as different Candida species showed moderate and strong biofilm production capacity (Table 4 ). It is thought that $C$. parapsilosis has the highest biofilm production capacity among non-albicans Candida species when considering the results of both previous reports and our study. ${ }^{20,21}$

\section{CONCLUSION}

It is understood that SSRI agents show in vitro antifungal and antibiofilm activity against Candida albicans, C. tropicalis, C. parapsilosis, and C. glabrata strains at different concentration levels, based on our findings and other studies in the literature. In addition to the antifungal activity of SSRIs, it was also detected that these agents in combination with FLC could have a synergistic effect against Candida spp. The effects of SSRIs on mature biofilms were investigated in the present study and it was found that SRT and FLX molecules could have antibiofilm effects against Candida species. Given all these results and studies, it is thought that these agents could have potential as adjuvant therapeutic agents. Research that will be conducted on the antibiofilm activities of SSRIs can be beneficial for the development of new antifungal and antibiofilm 
drug combinations and understanding the mechanisms of their antifungal effects.

Conflicts of interest: No conflict of interest was declared by the authors. The authors alone are responsible for the content and writing of the paper.

\section{REFERENCES}

1. Guinea J, Sánchez-Somolinos M, Cuevas O, Peláez T, Bouza E. Fluconazole resistance mechanisms in Candida krusei: the contribution of efflux-pumps. Med Mycol. 2006;44:575-578.

2. Shin JH, Kee SJ, Shin MG, Kim SH, Shin DH, Lee SK, Suh SP, Ryang DW. Biofilm production by isolates of Candida species recovered from nonneutropenic patients: Comparison of bloodstream isolates with isolates from other sources. J Clin Microbiol. 2002;40:1244-1248.

3. Paulone S, Ardizzoni A, Tavanti A, Piccinelli S, Rizzato C, Lupetti A, Colombari B, Pericolini E, Polonelli L, Magliani W, Conti S, Posteraro B, Cermelli C, Blasi E, Peppoloni S. The synthetic killer peptide KP impairs Candida albicans biofilm in vitro. PLoS One. 2017;12:1-16.

4. Gao Y, Li H, Liu S, Zhang X, Sun S. Synergistic effect of fluconazole and doxycycline against Candida albicans biofilms resulting from calcium fluctuation and downregulation of fluconazole-inducible efflux pump gene overexpression. J Med Microbiol. 2014;63:956-961.

5. Pesee S, Angkananuwat C, Tancharoensukjit S, Muanmai S, Sirivan $P$, Bubphawas M, Tanarerkchai N. In vitro activity of Caspofungin combined with Fluconazole on mixed Candida albicans and Candida glabrata biofilm. Med Mycol. 2016;54:384-393.

6. Lass-Flörl C, Dierich MP, Fuchs D, Semenitz E, Ledochowski M. Antifungal activity against Candida species of the selective serotoninreuptake inhibitor, sertraline. Clin Infect Dis. 2001;33:135-136.

7. Def EE. EUCAST E.DEF 7.3.1. EUCAST Method for the determination of broth dilution minimum inhibitory concentrations of antifungal agents for yeasts 2017; (January). Available from: https://www.eucast.org/ astoffungi/publications_in_journals/

8. Lewis RE, Diekema DJ, Messer SA, Pfaller MA, Klepser ME. Comparison of E-test, chequerboard dilution and time-kill studies for the detection of synergy or antagonism between antifungal agents tested against Candida species. J Antimicrob Chemother. 2002;49:345-351.

9. Madariaga-Venegas $F$, Fernández-Soto $R$, Duarte LF, Suarez N, Delgadillo D, Jara JA, Fernández-Ramires R, Urzúa B, Molina-Berríos A. Characterization of a novel antibiofilm effect of nitric oxide-releasing aspirin (NCX-4040) on Candida albicans isolates from denture stomatitis patients. PLoS One. 2017;12:e0176755.

10. Pfaller MA, Castanheira M, Messer SA, Rhomberg PR, Jones RN. Comparison of EUCAST and CLSI broth microdilution methods for the susceptibility testing of 10 systemically active antifungal agents when tested against Candida spp. Diagn Microbiol Infect Dis. 2014;79:198204.

11. Zhai B, Wu C, Wang L, Sachs MS, Lin X. The antidepressant sertraline provides a promising therapeutic option for neurotropic Cryptococcal infections. Antimicrob Agents Chemother. 2012;56:3758-3766.

12. Oliveira AS, Martinez-de-Oliveira J, Donders GGG, Palmeira-de-Oliveira $\mathrm{R}$, Palmeira-de-Oliveira A. Anti-Candida activity of antidepressants sertraline and fluoxetine: effect upon pre-formed biofilms. Med Microbiol Immunol. 2018;207:195-200.

13. Costa Silva RA, da Silva CR, de Andrade Neto JB, da Silva AR, Campos RS, Sampaio LS, do Nascimento FBSA, da Silva Gaspar B, da Cruz Fonseca SG, Josino MAA, Grangeiro TB, Gaspar DM, de Lucena DF, de Moraes MO, Cavalcanti BC, Nobre Júnior HV. In vitro anti-Candida activity of selective serotonin reuptake inhibitors against fluconazoleresistant strains and their activity against biofilm-forming isolates. Microb Pathog. 2017;107:341-348.

14. DeVane CL. Pharmacokinetics of the selective serotonin reuptake inhibitors. J Clin Psychiatry. 1992;53:13-20.

15. Tremaine LM, Welch WM, Ronfeld RA. Metabolism and disposition of the 5-hydroxytryptamine uptake blocker sertraline in the rat and dog. Drug Metab Dispos. 1989;17:542-550.

16. Mukherjee PK, Chandra J. Candida biofilm resistance. Drug Resist Updat. 2004;7:301-309.

17. Azevedo MM, Cobrado L, Silva Dias A, Ramalho P, Pina-Vaz C and Rodrigues AG. Antibiofilm effect of cerium nitrate against bacteria and yeast. Microbiol Infect Dis. 2013;2011-2014.

18. Azeredo J, Azevedo NF, Briandet R, Cerca N, Coenye T, Costa AR, Desvaux $M$, Di Bonaventura $G$, Hébraud $M$, Jaglic $Z$, Kačániová $M$, Knøchel S, Lourenço A, Mergulhão F, Meyer RL, Nychas G, Simões M, Tresse O, Sternberg C. Critical review on biofilm methods. Crit Rev Microbiol. 2017;43:313-351.

19. Stepanović S, Vuković D, Hola V, Di Bonaventura G, Djukić S, Cirković I, Ruzicka F. Quantification of biofilm in microtiter plates: overview of testing conditions and practical recommendations for assessment of biofilm production by staphylococci. APMIS. 2007;115:891-899.

20. Udayalaxmi J, Shenoy N. Comparison between biofilm production, phospholipase and haemolytic activity of different species of Candida isolated from dental caries lesions in children. J Clin Diagn Res. 2016;10:DC21-DC23.

21. Dögen A, Sav H, Gonca S, Kaplan E, Ilkit M, Novak Babic M, GundeCimerman N, de Hoog GS. Candida parapsilosis in domestic laundry machines. Med Mycol. 2017;55:813-819. 